\title{
Positive Psychology: Introduction to the Special Issue (In memoriam: Chris Peterson)
}

\author{
Psicología Positiva: Introducción al número especial \\ (In memorian, Chris Peterson)
}

\author{
Carmelo Vazquez \\ President-Elect International Positive Psychology Association \\ Departament of Clinical Psychology \\ Faculty of Psychology \\ Complutense University (Madrid), Spain
}

\begin{abstract}
This special issue of Terapia Psicólogica includes relevant contributions to the field of Positive Psychology, written by international researchers on well-being from Chile, Canada, Italy, Mexico, Netherlands, Spain, and USA,. Rather than viewing the field complacently, this issue contains critical reviews of the literature, which raises intriguing questions about the interpretation of past research and the possibility of answering those questions in the future. Original research is also presented and the methods used are both correlational and experimental, with cross-sectional and longitudinal designs. The content of these works include developmental and health-related issues, the positive and negative impact of traumatic experiences, and the effect of controlled experimental interventions on improving well-being. In conclusion, this issue reflects the increasing maturity of the Positive Psychology field and the growing complexity of the issues addressed as well as the methodologies used.

\section{Resumen}

Este número especial de Terapia Psicológica incluye contribuciones relevantes en el campo de la Psicología Positiva, escritas por investigadores internacionales de Chile, Canadá, Italia, México, Holanda, España y EE.UU. En lugar de ver el campo con complacencia, este número contiene revisiones críticas de la literatura, lo que plantea preguntas interesantes acerca de la interpretación de los estudios previos y la posibilidad de responder a estas cuestiones en el futuro. También se presenta investigación original, utilizando métodos correlacionales y experimentales, así como diseños de tipo transversal y longitudinal. El contenido de estos trabajos incluye temas de desarrollo y de salud, el impacto positivo y negativo de las experiencias traumáticas, y el efecto de las intervenciones experimentales controladas en la mejora del bienestar. En conclusión, este número refleja la creciente madurez del campo de la Psicología Positiva y la progresiva complejidad de los temas abordados y de las metodologías utilizadas.
\end{abstract}




\section{"Other people matter" \\ Christopher Peterson (1950-2012)}

During the preparation of this monograph, generously and enthusiastically encouraged by the journal Terapia Psicológica and Pablo Vera-Villarroel, its director, we were shocked by the unexpected passing of Chris Peterson, one of the principal and most impressive driving forces behind positive psychology, who had committed to contributing to this special issue of the journal.

Using the phrase "other people matter," the unforgettable Chris opened the First World Congress on Positive Psychology of the International Positive Psychology Association with a vibrant presentation in Philadelphia in 2009. Chris was a living and inspiring example of something highly valued in positive psychology: a persistent dedication to studying what makes life worth living, utilizing the best available methods in psychology. Accepting to participate in this issue of the journal Terapia Psicológica was a demonstration of how "other people matter." People really mattered to Chris Peterson, and his friends really mattered to him. A fun and creative person who was close to us has left us, and the indelible trace of him will be our guiding light. From an academic viewpoint, Chris was admirable because, among other qualities, he was capable of seeing what we couldn't see in our surroundings. In this ability lay his extraordinary contribution, above all others, in bringing the theme of psychological strengths and virtues to the game table of psychology (Peterson \& Seligman, 2004). Chris had a good life and knew how to transmit his spirit to others around him. In this issue, we take the opportunity to honor his memory through his own contribution, which was finally completed by his colleague Nansook Park who I am especially grateful to for her feat in such difficult conditions.

Positive psychology analyzes the good life. Although some doubt that this is a space where science can be done, I believe that there is probably no greater challenge that we can tackle. Psychology should confront this challenge as it admits that our obligation as scientists and professionals is to assure the best conditions of life for people. What can be more important? It doesn't seem like this would be difficult to understand, although there are bitter critics who consider this to be an insignificant objective outside the scope of science. This is more an emotional prejudice than an argument that can be backed by reason.

In this issue, international specialists renowned for their study of positive characteristics of human functioning have contributed with enormous generosity. Contributions include original studies related to health, organizations, and psychotherapies as well as updated reviews on current themes of interest.

Park, Peterson, and Sun (2013) conduct a succinct review of the principal areas that positive psychology covers. In this work, they reexamine relevant data of research on positive emotions, character strengths, positive relationships, and a meaningful life. The authors reflect on the implications that this research can have on practice, above all with respect to evaluation and intervention.

Does having children or taking care of them beget more happiness? The work of Della Fave et al. (2013) responds to this question, which seems easy to answer. In this work, the authors not only analyze psychopathological symptoms that can be associated with pregnancy and childbirth (fundamentally, depressive symptoms), but also analyze factors related to hedonic and eudaimonic well-being. Although taking care of children was questioned as a source of everyday happiness by Nobel Prize winner Daniel Kahneman (Kahneman et al., 2004), more recent research focused on the theme has dispelled his uncertainty (Nelson et al., 2013). In the same way, the results obtained in this longitudinal study of Della Fave and her colleagues -one of their strengths- support the idea that maternity is linked (at least during gestation and the first months) to elevated states of well-being despite existing difficulties in the process.

A repeated and relatively frequent criticism of positive psychology is that it doesn't contribute anything new. We don't need to test this to verify that it isn't true. In the last few years, to a large extent due to the impulse of positive psychology, new themes have been incorporated into psychological research (e.g., gratitude, compassion, appreciation for beauty, etc.) or rather, there have been initial scientific contributions on these themes. A perfect example is Robert Vallerand's systematic line of work on passion, a subject of special relevance that had been forgotten by psychology (and naturally, not so much by philosophy). Vallerand and Verner-Filion (2013) concisely set out the available evidence to support the Dualistic Model of Passion. In their contribution based on very varied data, Vallerand and his colleague express the necessity to distinguish between harmonious and obsessive passion given their distinct implications in levels of health, adaptation, and emotional well-being.

It can seem like positive psychology recommends unlimited doses of positive emotions, well-being, and excellence. This is a superficial interpretation. According to the Aristotelian concepts of virtue, it's probable that intermediate doses of positive features, emotions, or qualities are more adaptive than extremely elevated doses. In reality, this is a variation of the well-known inverted U-shaped effect that is also applicable to good things in life (Grant \& Schwartz, 2011). From a clinical perspective, Ruini and Fava (2013) lay out similar cautions with respect to clinical interventions and the risk of believing in unlimited levels of positive characteristics (mania is a good case study). In this work, the authors suggest that Well-Being Therapy, inspired by the ideas of Carol Ryff, can be an adequate channel to carry out balanced interventions to improve well-being. 
A highly active area of positive psychology is related to the positive aspects of adversity. Traditional models of the answer to stress and adversity have barely taken into account the possibility that trauma can be associated with something positive (Joseph, 2011). Various articles of this special issue are related to this important subject. A significant percentage (around 60\%) of people who have undergone serious hardships discover some benefit to the pain and adversity (Hegelson et al., 2006). In an empirical work, Chaves et al. (2013) analyze personal well-being from a multidimensional perspective (including measures of hedonic and eudaimonic well-being) and the perception of benefits in children with serious illnesses. Although research about the effects of serious illnesses on children has traditionally centered on the most adverse consequences (e.g., psychopathological problems), in the last few years, there is growing interest in completing that panorama with additional measures on positive psychological factors. Employing a wide battery of hedonic and eudaimonic measures, the study shows that children are capable of finding benefit in their situation (what can psychologically be an important anchoring element for recuperation) and further, that this perception of positive consequences is not due to a mere absence of psychological problems but to the robust relationship between this perception and other measures (e.g., of positive emotions). The study is another demonstration that positive mental health has distinguishing features from mental pathology (Keyes, 2007) and furthermore, there are evident signs of this positive aspect of health in very adverse circumstances.

In her contribution, Crystal Park, an international leader in the area, gives an update on the existing theories around posttraumatic growth, revealing the conceptual and methodological difficulties of its study (Cho \& Park, 2013). There is special emphasis on the necessity to look for indicators of growth that go beyond subjective opinions of participants on which, unfortunately, the majority of existing studies are founded. Although this is a methodological limitation of studies concerning growth after trauma (Bonanno, 2012), it is not exclusive to positive psychology but is relevant to a good part of current psychology in general. There is a need to go beyond subjective reports as the final or exclusive source of validation to pay more attention to what has historically always been the final reference: behavior (Baumeister et al., 2007). Positive psychology must maximize its effort to find objective indicators of results in addition to habitual subjective indicators. Whatever the case, Cho and Park (2013) make a stimulating proposal explaining the phenomenon of posttraumatic growth.

On more concrete terrain, Ochoa et al. (2013) explore a field of great interest: the experience of growth not only in those who suffer trauma but also in those close to the sufferer (e.g., family). This fact is fascinating as it delves into the analysis of how lives are intertwined and mutually affect each other (both in pain and in possible accompanying growth). In their study, Cristian Ochoa and his collaborators analyze the existing literature to distinguish between vicarious growth (due to learning and observing the sufferer's behavior) and secondary growth (the experience of growth in the companion as a product of proximity to the sufferer's trauma). A highlighting aspect of this work is the authors' meticulously in-depth study of the existing literature to contrast a series of hypotheses about the mechanisms of vicarious versus secondary posttraumatic growth.

One of the most important contributions of Positive Psychology is its research on intervention methods for increasing and sustaining well-being. Most of this research initially comes from highly controlled experimental studies which can then be successfully transferrable to the clinical field (Sin \& Lyubomirsky, 2009). Although there are many issues to address regarding the mechanism of the interventions (Lyubomirsky and Layous, 2013), this research is one of the most promising areas in the development of Positive Psychology. Madelon Peters and her team have conducted a study that further advances our understanding of the comparative effectiveness of several techniques on different well-being measures. In a well-controlled experimental study, they found that the "best possible self" intervention can have a more profound impact on optimism than a gratitude exercise. This line of research is critical in improving our knowledge of the best intervention methods we need to improve well-being.

In another contribution to this special issue, Bilbao et al. (2013) analyze an exciting yet unexplored subject: the impact that positive compared with negative events have on transforming our most basic beliefs. For years, it has been acknowledged that traumatic experiences can undermine or shake deep beliefs about oneself or the world (JanoffBulman, 1999), and some articles in this issue deal precisely with this. However, it's much less known to what extent intense positive experiences can transform and strengthen nuclear beliefs. The study of Bilbao and colleagues shows, faced with what has habitually been upheld (Baumeister et al., 2001), good deeds can be more powerful than the negative in fostering profound cognitive changes, which opens a very interesting line of research.

Marisa Salanova and her group (2013) synthesize intervention methods to form a HEalthy and Resilient Organization (HERO). One of the most interesting aspects of positive psychology is that it has been capable of uniting the interests of researchers and professionals in diverse fields, a rarity in psychology. As Seligman and Csikszentmihalyi (2000) noted, the purpose of positive psychology is the study of positive emotions, strengths, and institutions. Salanova and her group's aricle is an interesting example of the multidimensionality of positive psychology insofar as they present organizational interventions 
derived from exercises and strategies designed to improve and maintain individual well-being. Incidentally, some of these techniques are utilized in the clinical and health fields (e.g., gratitude exercises). How can the emotional climate of organizations be improved? How can organizations be made more healthy and effective? Beyond the rhetoric or traditional logic of the perspective of human resources, this contribution proposes, in a more fundamental way, the possibility of answering these questions from basic elements of research in positive psychology.

Positive psychology has noticeable connections with age-old traditions of psychology. For example, its link to humanist traditions is well known. Yet, it is stimulating to find new connections that are more unexpected. Margarita Tarragona (2013) poses an interesting dialogue between assumptions of constructive therapies (especially narrative and solution-focused therapies) and positive therapeutic approaches. A common point in both therapeutic perspectives is their rejection of a deficit model that ignores the resources and capacities of the patient. Under this shared element, the author assembles an interesting fabric of common links that deserve to be explored in the future. The challenge, naturally, is in being able not only to establish lines of connection but also to carefully investigate similarities and differences, and use research to identify the most effective approaches.

Finally, Parks and Szanto (2013) present an innovative pilot study which compares the efficacy of self-help books on improving participants' mood. One of the challenges for positive interventions is to assure that they add something to other already available therapeutic modalities (Mongrain and Anselmo-Mathews, 2012). In this paper, the authors compare a cognitive-behavioral approach with a positive psychology approach and a control condition using several outcome parameters in a non-clinical population. One interesting finding is that positive interventions are at least as useful as standard CBT methods although the former may have the added value of being more meaningful than the latter. Although further research is needed, this supplementary effect on meaning of positive psychology-based exercises might enhance, the efficacy of positive interventions.

We believe that this special issue is an adequate representation of positive aspects of human functioning with contributions from empirical research as well as critical and comprehensive literature reviews. Without doubt, the field of positive psychology is much broader (Vázquez \& Hervás, 2008) and it would be presumptuous to try and completely cover the growing complexity of this area and the overwhelming amount of existing evidence (e.g., Boehm \& Kubzansky, 2012; Lamers et al., 2012). Nevertheless, I believe that the presented contributions do largely reflect the maturity of certain areas, and the critical and demanding spirit of those who self-identify under the rubric of positive psychology. To make psychology positive does not imply giving up investigation of the limitations and problems of human beings, or even imply disregarding that suffering is a condition associated with our human experience. Those who assert this are creating a false and self-interested caricature of what is truly positive psychology.

To want to know more about human well-being and its advancement does not signify turning a blind eye to the recognition of pain and the necessity to recognize and overcome difficulties. However, I believe that positive psychology adds a certain awareness, without further pretensions, to investigating psychology that has omitted essential aspects of understanding human nature (Avia \& Vázquez, 1998). And we do research, proudly, with the best available theoretical and methodological knowledge of science. Positive psychology has come to stay and no one should question the legitimacy of our aim.

\section{References}

Avia, M.D., \& Vazquez, C. (1998). Optimismo inteligente. Psicología de las emociones positivas. (Prefacio by Martin E.P. Seligman). [Intelligent optimism. Psychology of positive emotions. (Preface by Martin E.P. Seligman)]. Madrid: Alianza Editorial.

Baumeister, R. F., Bratslavsky, E., Finkenauer, C. \& Vohs, K. D. (2001). Bad is stronger than good. Review of General Psychology, 5, 323-370.

Baumeister, R.F., Vohs, K.D., \& Funder, D.C. (2007). Psychology as the science of self-reports and finger movements: Whatever happened to actual behavior? Perspectives on Psychological Science, 2, 396-403.

Bilbao, M.A., Paéz, D., da Costa, S., \& Martínez-Zelaya, G. (2013). Cambio en creencias básica y crecimiento pos estrés: un estudio transversal sobre el fuerte impacto de los hechos positivos sobre el bienestar. Terapía Psicológica, 31, 127-139.

Boehm, J. K., \& Kubzansky, L. D. (2012). The heart's content: the association between positive psychological well-being and cardiovascular health. Psychological Bulletin, 138(4), 655-91. doi:10.1037/a0027448

Bonanno, G. A. (2012). Uses and abuses of the resilience construct: loss, trauma, and health-related adversities. Social Science \& Medicine, 74(5), 753-756. doi:10.1016/j.socscimed.2011.11.022

Chaves, C., Vazquez, C., \& Hervas, G. (2013). Benefit finding and wellbeing in children with life threatening illnesses: An integrative study. Terapia Psicológica,31, 59-68.

Cho, D., \& Park, C.L. (2013). Growth following trauma: Overview and current status. Terapia Psicológica,31, 69-79.

Delle Fave, A., Pozzo, M., Bassi, M., \& Cetin, I. (2013). A longitudinal study on motherhood and well-being: Developmental and clinical implications. Terapia Psicológica, 31, 21-33.

Grant, A. M., \& Schwartz, B. (2011). Too much of a good thing: The challenge and opportunity of the inverted U. Perspectives on Psychological Science, 6(1), 61-76. doi:10.1177/1745691610393523

Helgeson, V.S., Reynolds, K.A., \& Tomich, P. L. (2006). A meta-analytic review of benefit finding and growth. Journal of Consulting and Clinical Psychology, 74, 797-816.

Janoff-Bulman, R. (1992). Shattered assumptions: Towards a new psychology of trauma. New York: The Free Press.

Joseph, S. (2011). What doesn't kill us: The new psychology of posttraumatic growth. New York: Basic Books.

Kahneman, D., Krueger, A. B., Schkade, D. A., Schwarz, N., \& Stone, A. A. (2004). A survey method for characterizing daily life experience: The day reconstruction method. Science, 306, 1776-1780.

Keyes, C. L. M. (2007). Promoting and protecting mental health as flourishing: A complementary strategy for improving national mental health. American Psychologist, 62, 95-108.

Lamers, S. M. a, Bolier, L., Westerhof, G. J., Smit, F., \& Bohlmeijer, E. T. (2012). The impact of emotional well-being on long-term recovery 
and survival in physical illness: a meta-analysis. Journal of Behavioral Medicine, 35, 538-47.

Lyubomirsky, S., \& Layous, K. (2013). How do simple positive activities increase well-being? Current Directions in Psychological Science. DOI: 10.1177/0963721412469809

Mongrain, M., \& Anselmo-Matthews, T. (2012). Do positive psychology exercises work? A replication of Seligman et.al. (2005). Journal of Clinical Psychology, 68, 382-389.

Nelson, S.K., Kushlev, K., English, T., Dunn, E.W., \& Lyubomirsky, S. (2013). In defense of parenthood: children are associated with more joy than misery. Psychological Science, 24, 3-10

Ochoa, C., Castejón, V., Sumalla, E.C., \& Blanco, I. (2013). Crecimiento posttraumático en supervivientes de cáncer y sus otros significativos: ¿Crecimiento vicario o secundario? Terapia Psicológica, 31, 81-92.

Park, N., Peterson, C., \& Sun, J.K. (2013). La psicología positiva: Investigación y aplicaciones. Terapia Psicológica, 31, 11-19.

Parks, A.C., \& Szanto, R.K. (2013). Assessing the efficacy and effectiveness of a positive psychology-based self-help book. Terapia Psicológica, 31, 141-149.
Peters, M.L., Meevissen, Y.M., \& Hanssen, M.M. (2013). Specificity of the Best Possible Self intervention for increasing optimism: Comparison with a gratitude intervention. Terapia Psicológica, 31, 93-100.

Ruini, C., \& Fava, G.A. (2013). The polarities of psychological well being and their response to treatment. Terapia Psicológica, 31, 49-57.

Salanova, M., Llorens, S., Acosta, H., \& Torrente, P. (2013). Positive interventions in positive organizations. Terapia Psicológica, 31, 101-113.

Seligman, M.E.P., \& Csikszentmihalyi, M. (2000). Positive psychology: An introduction. American Psychologist, 55, 5-14.

Sin, N. L., \& Lyubomirsky, S. (2009). Enhancing well-being and alleviating depressive symptoms with positive psychology interventions: A practice-friendly meta-analysis. Journal of Clinical Psychology, 65, 467-487.

Tarragona, M. (2013). Psicología positiva y terapias constructivas: Una propuesta integradora. Terapia Psicológica, 31, 115-125.

Vallerand, R.J., \& Verner-Filion, J. (2013). Making people's life most worth living: On the importance of passion for positive psychology. Terapia Psicológica, 31, 35-48.

Vázquez, C., \& Hervás, C. (Eds.). (2008). Psicología Positiva aplicada. [Applied Positive Psychology]. Bilbao: Desclee de Brower. 
